Det er mi nat i on of azi de i $\mathrm{n}$ bi ol ogi cal $\mathrm{fl}$ ui ds by use of el ectron par amagnet i c resonance

\begin{tabular}{|l|l|}
\hline 著者 & M nakat a Kayoko, Suzuki Osamu \\
\hline $\begin{array}{l}\text { j our nal or } \\
\text { publ i cat i on t i t l e }\end{array}$ & Anal yt i ca Chi mi ca Act a \\
\hline vol une & 554 \\
\hline number & $1-2$ \\
\hline page range & $202-206$ \\
\hline year & $2005-12-04$ \\
\hline URL & ht t p: //hdl . handl e. net /10271/41 \\
\hline
\end{tabular}




\title{
Determination of azide in biological fluids by use of electron paramagnetic resonance
}

\author{
Kayoko Minakata*, Osamu Suzuki
}

Department of Legal Medicine, Hamamatsu University School of Medicine, 1-20-1

Handayama, Hamamatsu 431-3192, Japan

\begin{abstract}
A simple and sensitive method has been developed for the determination of azide ion $\left(\mathrm{N}_{3}{ }^{-}\right)$in biological fluids and beverages. The procedure was based on the formation of a ternary complex $\mathrm{Cu}\left(\mathrm{N}_{3}\right)_{2}$ (4-methylpyridine $)_{\mathrm{x}}$ in benzene, followed by its detection by electron paramagnetic resonance. The complex in benzene showed a characteristic four-peak hyperfine structure with a $g$-value of 2.115 at room temperature. $\mathrm{Cu}^{2+}$ reacted with $\mathrm{N}_{3}{ }^{-}$most strongly among common metals found in biological fluids. Several anions and metal ions in biological fluids did not interfere with the determination of $\mathrm{N}_{3}{ }^{-}$in the presence of large amounts of $\mathrm{Cu}^{2+}$ and oxidants. In the present method, $\mathrm{N}_{3}{ }^{-}$at the concentration from $5 \mu \mathrm{M}$ to $2 \mathrm{mM}$ in $100 \mu \mathrm{l}$ solution could be determined with the detection limit of $20 \mathrm{ng}$. The recoveries were more than $95 \%$ for $\mathrm{N}_{3}{ }^{-}$added to $100 \mu \mathrm{l}$ of blood, urine, milk and beverages at $200 \mu \mathrm{M}$. Our method is recommendable because it takes less than 10 min to determine $\mathrm{N}_{3}{ }^{-}$and the produced complex is quite stable.
\end{abstract}


*Corresponding author. Tel/fax: +81-53-435-2233.

E-mail address: kminakat@ hama-med. ac.jp (K. Minakata)

Keywords: Azide; Electron paramagnetic resonance; Copper; Blood; Urine

\section{Introduction}

Sodium azide is used in industry as an explosive in automobile safety bags and an antifungal for diagnostic reagents. A few years ago, however, several poisoning cases of sodium azide occurred in Japan [1]. When poisoning occurred, quick and decisive determination of toxic substances is required using the sample as small as possible. Demonstration of the presence of azide ion $\left(\mathrm{N}_{3}{ }^{-}\right)$was mostly based on a color reaction [1-3]. A colorimetric determination of $\mathrm{N}_{3}{ }^{-}$in blood, beverages and waste-water, however, required large amounts of $\mathrm{N}_{3}{ }^{-}$, e.g., $4-20 \mu \mathrm{g}$. Also the measuring processes such as vaporization of $\mathrm{N}_{3}{ }^{-}$as $\mathrm{HN}_{3}$ gas and condensation of $\mathrm{HN}_{3}$ in alkaline solution to avoid interferences from the other substances resulted in 1 hr-measurement time. To avoid the distillation, a liquid chromatographic determination [4,5] was proposed using $80-200 \mathrm{ng} \mathrm{N}_{3}{ }^{-}$. Those methods, however, took time for the derivatization of $\mathrm{N}_{3}{ }^{-}$after the deproteinization of samples.

$\mathrm{N}_{3}{ }^{-}$is known to form immediately ternary complexes with transition metals in the presence of pyridine (Py), and the complexes can be extracted with chloroform [3]. These azide complexes were used for the colorimetric determination of either $\mathrm{N}_{3}{ }^{-}$or transition metals [1-3]; however, the molar absorption of azide complex with $\mathrm{Cu}$ in chloroform, $\varepsilon_{435}=2500$, was not large and less than twice that in aqueous solution, $\varepsilon$ $385=1600[2,3] . \quad$ The extraction of the complex with organic solvents reduced the 
interference by impurities to some extent.

$\mathrm{Cu}^{2+}$ having an EPR signal at room temperature was found to react with $\mathrm{N}_{3}{ }^{-}$most strongly among several transition metals commonly contained in biological fluids. In the present study, the applicability of the paramagnetic character of the complex of $\mathrm{N}_{3}{ }^{-}$with $\mathrm{Cu}^{2+}$ to the determination of $\mathrm{N}_{3}{ }^{-}$has been studied since only paramagnetic species could be sensitively detected by EPR method even for crude materials [6]. In benzene solution, the quantitation of the complex of $\mathrm{N}_{3}{ }^{-}$with $\mathrm{Cu}^{2+}$ means the quantitation of $\mathrm{N}_{3}^{-}$, since the present study showed that one $\mathrm{Cu}^{2+}$ ion combined with two $\mathrm{N}_{3}{ }^{-}$ions always in benzene, whereas one $\mathrm{Cu}^{2+}$ ion combined with either one, two or four $\mathrm{N}_{3}{ }^{-}$ions in water [2,3]. In addition, to extract $\mathrm{Cu}\left(\mathrm{N}_{3}\right)_{2}$ complex from aqueous crude samples, 4-methylpyridine (Mp) and benzene have been used in place of Py and chloroform used previously [3], to decrease nonspecific reactions of $\mathrm{Cu}^{2+}$ with anions contained in biological fluids and beverages.

\section{Experimental}

\subsection{Materials}

The chemicals of atomic absorption grade or of analytical grade were obtained from Wako Pure Chemical Ltd., Japan. A A 200- $\mu$ l polypropylene tube with cap was obtained from Eppendorf AG, Germany, a 20- $\mu$ l quartz hematocrit capillary for EPR measurement, from Drummond Scientific Co., USA, and putty for sealing the capillary, from Modulohm A/S, Denmark. Blood and urine were obtained from healthy volunteers with their informed consent. Beverages were obtained from local stores. A vortex mixer and a centrifuge with $6000 \mathrm{x}$ g were used to transfer $\mathrm{Cu}\left(\mathrm{N}_{3}\right)_{2}(\mathrm{Mp})_{\mathrm{x}}$ from 
water to benzene.

\subsection{Preparation of calibration and quality control samples}

Sodium azide dissolved in water at $1 \mathrm{M}$ was used as the stock solution. Standard solutions at $0.5,1.5,20,50$ and $200 \mathrm{mM} \mathrm{N}_{3}{ }^{-}$in $1 \mathrm{M} \mathrm{Na}_{2} \mathrm{SO}_{4}$ were prepared daily by using the stock solution,. To obtain calibration standards at 5, 15, 50, 200, 500 and $2000 \mu \mathrm{M} \mathrm{N}_{3}{ }^{-}, 1 \mu \mathrm{l}$ of appropriate standard solution was added to $99 \mu \mathrm{l}$ of sample, respectively. Intra-day variations were assessed on quality control samples at 5, 15, 50, 200, 500 and $2000 \mu \mathrm{M} \mathrm{N}_{3}{ }^{-}$by analyzing 6 times for each concentration on the same day. Inter-day variations were assessed on the quality control samples prepared and analyzed daily for 5 days. Recovery was calculated as the percentage of the concentration found in the sample to the nominal concentration spiked.

\subsection{EPR spectroscopy}

EPR measurements were performed on a JEOL JES-FE2XG ESR spectrometer, Japan. For determination of the hyperfine splitting and $g$-value, the calibration of magnetic field was performed by using signals of $\mathrm{Mn}^{2+}[6]$. Modulation width of 2 $\mathrm{mT}$ was found to be the most suitable setting. Microwave power of $65 \mathrm{~mW}$ was applied, since power saturation appeared at higher power than $70 \mathrm{~mW}$. Gain setting could be varied from 1 to $10^{4}$ according to signal heights. The accuracy of the EPR method was compared with a colorimetric method measured by a Shimadzu UV 2200 spectrophotometer, Japan. 


\subsection{Assay procedure for azide}

A $100-\mu l$ volume of sodium azide standard solution or each sample solution (except blood) is placed in a tube and mixed with $25 \mu \mathrm{l}$ of solution containing either 0.125 or $0.5 \mathrm{M} \mathrm{CuSO}_{4}$. The $\mathrm{pH}$ of the solution is adjusted to $4-8$ with either $\mathrm{NaOH}$ or $\mathrm{H}_{2} \mathrm{SO}_{4}$ solution, if necessary. In case of a blood sample, $100 \mu \mathrm{l}$ of blood is centrifuged to obtain plasma. To the precipitate, $25 \mu \mathrm{l}$ of $0.1 \mathrm{M} \mathrm{Na}_{2} \mathrm{SO}_{4}$ solution is added and mixed, followed by centrifugation to obtain the supernatant. This extraction is repeated once. The mixture of plasma and two supernatants is added with $25 \mu \mathrm{l}$ of solution containing both $2 \mathrm{M} \mathrm{Na}_{2} \mathrm{SO}_{4}$ and $0.125 \mathrm{M} \mathrm{CuSO}_{4}$. If the mixture of plasma and two supernatants contains hemoglobin, the mixture is heated for $2 \mathrm{~min}$ at $100{ }^{\circ} \mathrm{C}$ in a heat block.

To the solution prepared above, $20 \mu \mathrm{l}$ of benzene containing $10 \%(\mathrm{v} / \mathrm{v}) \mathrm{Mp}$ is added and mixed for $10 \mathrm{~s}$, and centrifuged for $30 \mathrm{~s}$. The benzene layer is shifted to another tube containing $10 \mu \mathrm{l}$ of $0.5 \mathrm{M} \mathrm{Na}_{2} \mathrm{SO}_{4}$ and mixed for $10 \mathrm{~s}$ to remove hydrophilic compounds from benzene layer. After centrifugation for $30 \mathrm{~s}, 10 \mu \mathrm{l}$ of benzene layer is placed in a quartz capillary, and put in EPR cavity. EPR spectrum is measured at $20{ }^{\circ} \mathrm{C}$ and, the difference in the peak at $319 \mathrm{mT}$ ( i.e. the vertical length between the signal top at $317 \mathrm{mT}$ and the signal bottom at $321 \mathrm{mT}$ ) is considered to be the amount of $\mathrm{N}_{3}{ }^{-}$. For the colorimetric measurements, the volumes of sample and reagents are proportionally increased at every step. 


\section{Results and discussion}

\subsection{EPR spectrum}

Figure 1 shows EPR spectra of $\mathrm{Cu}\left(\mathrm{N}_{3}\right)_{2}(\mathrm{Mp})_{\mathrm{x}}$ extracted into benzene from aqueous solutions at various concentrations of $\mathrm{N}_{3}{ }^{-}$. The EPR spectrum of $\mathrm{Cu}\left(\mathrm{N}_{3}\right)_{2}(\mathrm{Mp})_{\mathrm{x}}$ was characterized by 4 peaks with the hyperfine splitting of $5.8 \pm 0.1 \mathrm{mT}$ and the $g$-value of the center of the signal, $2.115 \pm 0.001$ as listed in Table $1 . \quad$ The line shapes of $\mathrm{Cu}\left(\mathrm{N}_{3}\right)_{2}(\mathrm{Mp})_{\mathrm{x}}$ complex in benzene extracted from several samples were the same as that extracted from aqueous standard solution, respectively. Therefore, the difference in the peak at $319 \mathrm{mT}$ could be used for quantitation of $\mathrm{N}_{3}{ }^{-}$in various samples.

\subsection{Suitable solvent and ternary component}

In the previous report [3] chloroform and Py had been used to extract $\mathrm{Cu}\left(\mathrm{N}_{3}\right)_{2}$ from water to an organic layer. In the present work, however, benzene and Mp were used due to following two reasons. Firstly, the interfering EPR signals in chloroform resulting from anions listed in group $\mathrm{C}$ of Table 2 were larger than those in benzene. For example, under the condition of $100 \mathrm{mM} \mathrm{Cu}^{2+}, 100 \mathrm{mM} \mathrm{Cl}^{-}$and $200 \mu \mathrm{M} \mathrm{N}_{3}{ }^{-}$, the signal of $\mathrm{Cu}(\mathrm{Cl})_{2}(\mathrm{Py})_{\mathrm{x}}$ was 1.9 times higher than that of $\mathrm{Cu}\left(\mathrm{N}_{3}\right)_{2}(\mathrm{Py})_{\mathrm{x}}$ in chloroform, whereas that of $\mathrm{Cu}(\mathrm{Cl})_{2}(\mathrm{Mp})_{\mathrm{X}}$ was 11 times lower than that of $\mathrm{Cu}\left(\mathrm{N}_{3}\right)_{2}(\mathrm{Mp})_{\mathrm{x}}$ in benzene. This may be due to higher polarity of chloroform than that of benzene, resulting in dissolution of weaker complexes between $\mathrm{Cu}^{2+}$ and interfering anions. Secondly, benzene layer is easy to take out, since it is lighter than the aqueous layer containing precipitates, whereas the chloroform layer sinks together with precipitates.

The ternary components such as Mp, 3-methylpyridine, 2-methylpyridine and Py were compared. The $g$-value, hyperfine splitting and relative signal height are listed 
in Table 1. The signal height decreased in the order of Mp, 3-methylpyridine and 2-methylpyridine, indicating that the methyl group at position 2 interfered with the complex formation of $\mathrm{N}$ atom in pyridine ring. The color of the complex of 2-methylpyridine was also the weakest among these complexes. When benzene was used as a solvent, Mp had to be used because of higher solubility of Mp than that of Py in benzene. Benzene containing $10 \% \mathrm{Mp}$ was used for the following study since the complete extraction of the complex was achieved with benzene containing 5 - $20 \%$ Mp.

\subsection{Molar ratio of $\mathrm{N}_{3}^{-}$to $\mathrm{Cu}^{2+}$}

To determine the molar ratio of $\mathrm{N}_{3}^{-}$to $\mathrm{Cu}^{2+}$ in the complex, the titration was performed as follows. Each 0 to $100 \mu \mathrm{l}$ of $2 \mathrm{mM} \mathrm{N}_{3}{ }^{-}$in $0.5 \mathrm{M} \mathrm{Na}_{2} \mathrm{SO}_{4}$ solution was mixed with 100 to $0 \mu \mathrm{l}$ of $1 \mathrm{mM} \mathrm{Cu}^{2+}$ in $0.5 \mathrm{M} \mathrm{Na}_{2} \mathrm{SO}_{4}$ solution, respectively, and they were extracted with $20 \mu \mathrm{l}$ of benzene containing $10 \% \mathrm{Mp}$, respectively. The maximum EPR signal was obtained when the molar ratio $\mathrm{N}_{3}{ }^{-} / \mathrm{Cu}^{2+}$ was 2 , where $\mathrm{N}_{3}{ }^{-}$ was converted to $\mathrm{Cu}\left(\mathrm{N}_{3}\right)_{2}(\mathrm{Mp})_{\mathrm{x}}$ in a $93 \%$ yield. When the molar ratio was smaller than 0.86, i.e., $3 \mathrm{mM} \mathrm{N}_{3}{ }^{-}$and $3.5 \mathrm{mM} \mathrm{Cu}^{2+}$ in benzene, $\mathrm{N}_{3}{ }^{-}$was converted to $\mathrm{Cu}\left(\mathrm{N}_{3}\right)_{2}(\mathrm{Mp})_{\mathrm{x}}$ in a $100 \%$ yield. $\quad$ Species like $\mathrm{CuN}_{3}{ }^{+}$and $\mathrm{Cu}\left(\mathrm{N}_{3}\right)_{4}{ }^{2-}$ were observed in aqueous solution [2,3]. Therefore, $\mathrm{Na}_{2} \mathrm{SO}_{4}$ was added in the assay to extract $\mathrm{Cu}\left(\mathrm{N}_{3}\right)_{2}(\mathrm{Mp})_{\mathrm{x}}$ completely with benzene.

\subsection{Effect of anions}

$\mathrm{CuSO}_{4}$ was chosen as a source of $\mathrm{Cu}^{2+}$ since the final benzene layer extracted from 
even $1 \mathrm{M} \mathrm{CuSO}_{4}$ solution did not show any EPR signals. The effects of various anions were examined using $100 \mathrm{mM}$ each anion, $200 \mu \mathrm{M} \mathrm{N}_{3}{ }^{-}$and either 25 or $100 \mathrm{mM}$ $\mathrm{Cu}^{2+}$, because such anions are expected to be included at relatively high concentration in biological samples. The results are listed in Table 2. Anions in group A did not cause any errors at the concentrations of both 25 and $100 \mathrm{mM} \mathrm{Cu}^{2+}$. Anions in group B did not show any EPR signals and reduced the EPR signals of $\mathrm{Cu}\left(\mathrm{N}_{3}\right)_{2}(\mathrm{Mp})_{\mathrm{x}}$ only when their concentrations were higher than those of $\mathrm{Cu}^{2+}$; they caused negative errors at $25 \mathrm{mM} \mathrm{Cu}^{2+}$ but not at $100 \mathrm{mM} \mathrm{Cu}^{2+}$, indicating that some extent of $\mathrm{Cu}^{2+}$ was consumed for formation of complexes with these anions in group B. Anions in group C showed small EPR signals of their complexes with $\mathrm{Cu}^{2+}$ in benzene having different hyperfine structures and $g$-values from those of $\mathrm{N}_{3}{ }^{-}$, but interfered with the determination of $\mathrm{N}_{3}{ }^{-}$when the concentrations of $\mathrm{N}_{3}{ }^{-}$were low and the concentrations of the anions were high. Especially, concentrations of $\mathrm{Cl}^{-}$are close to $100 \mathrm{mM}$ in human blood and urine. Although the binding of $\mathrm{Cl}^{-}$with $\mathrm{Cu}^{2+}$ is weak, the possibility of interference by $\mathrm{Cl}^{-}$should be kept in mind when samples containing low concentration of $\mathrm{N}_{3}{ }^{-}$are dealt with. Therefore, the steps of washing out hydrophilic compounds into $0.5 \mathrm{M} \mathrm{Na}_{2} \mathrm{SO}_{4}$ solution were added in the assay. When benzene containing weak $\mathrm{Cu}^{2+}$ complexes with anions, such as $\mathrm{Cu}(\mathrm{Cl})_{2}(\mathrm{Mp})_{\mathrm{x}}$ and $\mathrm{Cu}\left(\mathrm{NO}_{3}\right)_{2}(\mathrm{Mp})_{\mathrm{x}}$, was mixed with $0.5 \mathrm{M} \mathrm{Na}_{2} \mathrm{SO}_{4}$ solution, these complexes were dissolved in aqueous layer showing no EPR signals in benzene layer. In contrast, $\mathrm{Cu}\left(\mathrm{N}_{3}\right)_{2}(\mathrm{Mp})_{\mathrm{x}}$ remained in benzene layer completely, making the determination of $5 \mu \mathrm{M}$ $\mathrm{N}_{3}{ }^{-}$possible as shown in Fig. 1 (c). Anions in group $\mathrm{D}, \mathrm{I}^{-}, \mathrm{NO}_{2}{ }^{-}$and $\mathrm{SCN}^{-}$showed large EPR signals of their complexes with $\mathrm{Cu}^{2+}$ in benzene having different hyperfine 
structures and $g$-values from those of $\mathrm{N}_{3}{ }^{-}$, but they did interfere with the determination of $\mathrm{N}_{3}{ }^{-}$. However, this problem could be overcome by adding a 4-fold molar amount of $\mathrm{KMnO}_{4}$ to the test solution to oxidize $\mathrm{I}^{-}, \mathrm{NO}_{2}{ }^{-}$or $\mathrm{SCN}^{-}$. After $5 \mathrm{~min}$, any EPR signals originated from either $\mathrm{I}^{-}, \mathrm{NO}_{2}{ }^{-}, \mathrm{SCN}^{-}$or $\mathrm{KMnO}_{4}$ were not observed. In $\mathrm{KMnO}_{4}$ solution, however, $\mathrm{N}_{3}{ }^{-}$could be measured without its oxidation when the $\mathrm{pH}$ of the solution was higher than 7.

\subsection{Effect of metal ions}

The effects of various metal ions on the present assay were examined at the concentrations of $1 \mathrm{mM}$ each ion, $1 \mathrm{mM} \mathrm{Cu}^{2+}$ and $5 \mathrm{mM} \mathrm{N}_{3}^{-}$. The production rate of $\mathrm{Cu}\left(\mathrm{N}_{3}\right)_{2}(\mathrm{Mp})_{\mathrm{x}}$ from solution containing both test ion and $\mathrm{Cu}^{2+}$ was compared with that of the solution without the test ion. As results, there was no interference by $\mathrm{V}^{5+}$, $\mathrm{Cr}^{6+}, \mathrm{Cr}^{3+}, \mathrm{Mn}^{7+}, \mathrm{Mn}^{2+}, \mathrm{Fe}^{3+}, \mathrm{Fe}^{2+}, \mathrm{Co}^{2+}, \mathrm{Ni}^{2+}, \mathrm{Zn}^{2+}, \mathrm{As}^{3+}, \mathrm{Se}^{4+}, \mathrm{Mo}^{6+}, \mathrm{Ag}^{+}, \mathrm{Cd}^{2+}, \mathrm{W}^{6+}$, $\mathrm{Pb}^{2+}$ and $\mathrm{La}^{3+}$. The production rates were reduced in the solutions containing following four metals: $50 \%$ reduction by $\mathrm{Pd}^{2+}, 40 \%$ by $\mathrm{Ti}^{4+}$ and $\mathrm{Zr}^{4+}$, and $20 \%$ by $\mathrm{Ru}^{3+}$, respectively. However, the production rates of $\mathrm{Cu}\left(\mathrm{N}_{3}\right)_{2}(\mathrm{Mp})_{\mathrm{x}}$ could be recovered to more than $95 \%$ when the concentrations of these four metals were decreased to one tenth of $\mathrm{Cu}^{2+}$ concentration. All metal ions mentioned above did not show any EPR signals derived from complexes between each metal ion and $\mathrm{N}_{3}{ }^{-}$.

\subsection{Optical absorption and concentration linearity}

The optical absorption spectrum of $\mathrm{Cu}\left(\mathrm{N}_{3}\right)_{2}(\mathrm{Mp})_{\mathrm{x}}$ in benzene showed its maximum at $435 \mathrm{~nm}$. The $\varepsilon$ value at $435 \mathrm{~nm}$ was 2500 , the same as that of $\mathrm{Cu}\left(\mathrm{N}_{3}\right)_{2}(\mathrm{Py})_{\mathrm{x}}$ in 
chloroform [3]. The concentrations of $\mathrm{N}_{3}{ }^{-}$from 0 to $500 \mu \mathrm{M}$ measured by EPR method (y in $\mu \mathrm{M}$ ) and those measured by colorimetric method ( $\mathrm{x}$ in $\mu \mathrm{M}$ ) were well satisfied with the equation $y=1.00 x+3.5$ with the correlation coefficient of 0.99 .

The calibration equations calculated on 36 points (six concentrations such as 5, 15, 50, 200, 500 and $2000 \mu \mathrm{M}$, six determinations per each concentration) were excellent for all six samples as listed in Table 3.

\subsection{Stability and recovery}

The $\mathrm{Cu}\left(\mathrm{N}_{3}\right)_{2}(\mathrm{Mp})_{\mathrm{x}}$ complex in benzene was quite stable; more than $95 \%(n=6)$ remained unchanged after 7 days, when it was kept in a tube with a tight cap under room light at room temperature. In the assay of $\mathrm{N}_{3}^{-}$in beverages such as coffee, green tea and orange juice, $100 \mathrm{mM} \mathrm{Cu}^{2+}$ was used instead of $25 \mathrm{mM} \mathrm{Cu}^{2+}$ used for aqueous solution, blood, urine and milk, respectively. $\quad$ The lower recoveries from beverages at $25 \mathrm{mM} \mathrm{Cu}^{2+}$ indicated that $\mathrm{Cu}^{2+}$ was consumed to form water-soluble complexes with various substances, such as citric acid and ascorbic acid.

Recovery and coefficient of variation of the determination for $\mathrm{N}_{3}{ }^{-}$spiked into $100 \mu \mathrm{l}$ of biological fluids at 5 - $200 \mu \mathrm{M}$ are listed in Table 4. The corresponding values for the solutions spiked at 5, 500 and $2000 \mu \mathrm{M}$ were not listed in the table, since the recoveries were lower than $37 \%$ at $5 \mu \mathrm{M}$ in all six samples, whereas the deviation from the nominal value as well as the coefficient of variation of determination were lower than $5 \%$ at 500 and $2000 \mu \mathrm{M}$ in all six samples, respectively. When blood was hemolyzed, however, the recovery was reduced according to the degree of hemolysis, irrespective to the concentrations of $\mathrm{Cu}^{2+}$. The recoveries of $\mathrm{N}_{3}{ }^{-}$at $200 \mu \mathrm{M}$ were $0 \%$ 
and $80 \%$ in hemolyzed blood and in the heat-denatured hemolyzed blood, respectively. This suggests that intact hemoglobin combines with $\mathrm{N}_{3}{ }^{-}$but denatured one does not. Large amounts of substances in any of matrices were confirmed not to exhibit EPR signals in benzene layer, shown in Fig. 1(d) as an example of blood.

\subsection{Accuracy, precision, limit of quantitation and limit of detection}

Fig. 1 (c) shows the spectrum of $20 \mathrm{ng}$ of $\mathrm{N}_{3}{ }^{-}$extracted from $100 \mu \mathrm{l}$ aqueous solution at $5 \mu \mathrm{M}$. Here, $5 \mu \mathrm{M}$ is considered as the limit of detection in aqueous solution, since characteristic 4-peak structure can be observed and $\mathrm{S} / \mathrm{N}$ ratio is better than 3 at the concentration higher than $5 \mu \mathrm{M}$. Limit of quantitation in aqueous solution was 15 $\mu \mathrm{M}$, since the deviation from the nominal value as well as the coefficient of variations of six determinations was less than $5 \%$ when the concentration was higher than $15 \mu \mathrm{M}$. Intra-day and inter-day variation of recovery and coefficient of variation of the determination for $\mathrm{N}_{3}{ }^{-}$, spiked into $100 \mu \mathrm{l}$ of biological fluids at $15-200 \mu \mathrm{M}$ are listed in Table 4. The limit of quantitation was $50 \mu \mathrm{M}$ in these samples, since all the recoveries were in the range of $80-100 \%$, and all the coefficients of variation were lower than $20 \%$, respectively. The limit of detection in these samples was $15 \mu \mathrm{M}$, since 4-peak structure was observed and $\mathrm{S} / \mathrm{N}$ ratio was better than 3 at this concentration. The absolute amount of detection limit was $60 \mathrm{ng}$ of $\mathrm{N}_{3}{ }^{-}$using 100 $\mu \mathrm{l}$ of sample solution. The detection limits of the colorimetric method reported were $20 \mu \mathrm{g}$ [1] and $4 \mu \mathrm{g}$ [2], and those of HPLC method, $80 \mathrm{ng}$ [4] and $200 \mathrm{ng}$ [5], respectively, using $1 \mathrm{ml}$ of sample solution in each method. 


\section{Conclusion}

In the present method $\mathrm{N}_{3}{ }^{-}$in plasma and urine was sensitively determined within 10 min without tedious distillation used in the colorimetric method $[1,2]$ and without derivatization of $\mathrm{N}_{3}{ }^{-}$used in the HPLC method [4,5]. This method can be used for the concentration of $\mathrm{N}_{3}{ }^{-}$. That is, $\mathrm{N}_{3}{ }^{-}$in aqueous solution was extracted with 0.2 volume of benzene as $\mathrm{Cu}\left(\mathrm{N}_{3}\right)_{2}(\mathrm{Mp})_{\mathrm{x}}$ and from that benzene, $\mathrm{N}_{3}{ }^{-}$was extracted again with 0.2 volume of $0.01 \mathrm{M} \mathrm{NaOH}$ solution, resulting in 25-fold concentration with $90 \%$ recovery of $\mathrm{N}_{3}{ }^{-}$.

Acknowledgment This work was supported by a Grant-in-Aid for Scientific Research (15590576) from the Ministry of Education, Science, Sports and Culture of Japan.

\section{References}

[1 K. Tsuge, M. Kataoka, Y. Seto. J. Anal. Toxicol. 25 (2001) 228.

[2] E.A. Neves, E. De Oliveira, L. Sant’ Agostino. Anal. Chim. Acta 87 (1976) 243.

[3] R.G. Clem, E.H. Huffman. Anal. Chem. 38 (1966) 926.

[4] W.E. Lambert, M. Piette, C. Van Peteghem, A.P. De Leenheer. J. Anal. Toxicol. 19 (1995) 261.

[5] P. Marquet, S. Clement, H. Lotfi, M.F. Dreyfuss, J. Debord, D. Dumont, G. Lachatre. J. Anal. Toxicol. 20 (1996) 134.

[6] K. Minakata, O. Suzuki. Anal. Chim. Acta 512 (2004) 355. 


\section{Figure captions}

Fig. 1. EPR spectra of $\mathrm{Cu}\left(\mathrm{N}_{3}\right)_{2}(\mathrm{Mp})_{\mathrm{x}}$ complex in $10 \mu \mathrm{l}$ of benzene as a function of $\mathrm{N}_{3}{ }^{-}$ concentrations. (a): extract from $200 \mu \mathrm{M} \mathrm{N}_{3}{ }^{-}$aqueous solution measured at gain setting of 160 . (b): $\mathrm{Mn}^{2+}$ in $\mathrm{MgO}$ was measured together with $\mathrm{Cu}\left(\mathrm{N}_{3}\right)_{2}(\mathrm{Mp})_{\mathrm{x}}$ to calibrate the magnetic field. (c): extract from $5 \mu \mathrm{M} \mathrm{N}_{3}{ }^{-}$aqueous solution measured at gain setting of 2000. (d): extract from $\mathrm{N}_{3}{ }^{-}$-free blood measured at gain setting of 2000.

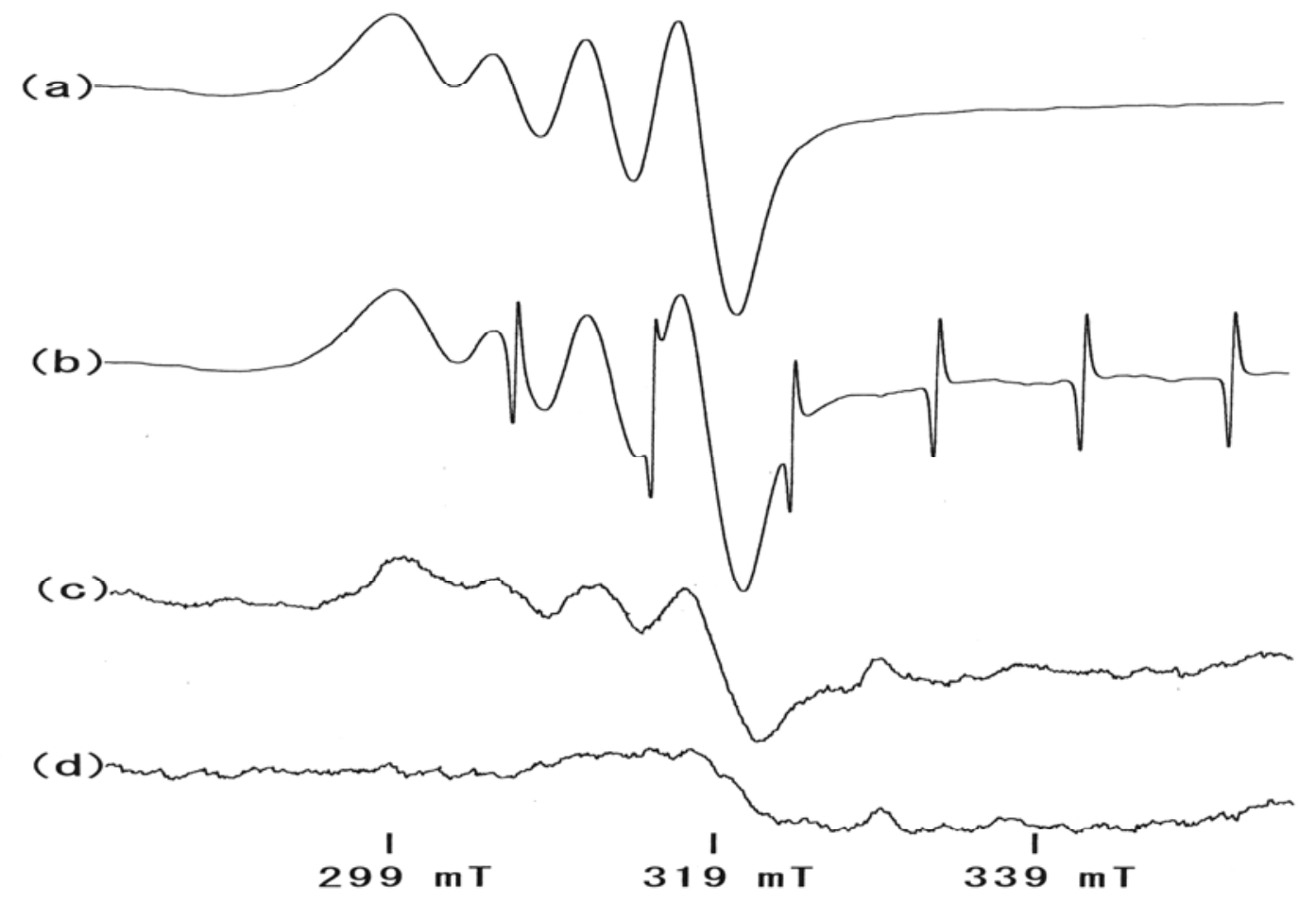


Table 1

EPR parameters of Cu-azide complexes

\begin{tabular}{|lccc|}
\hline Components & $g$-Value & $\begin{array}{c}\text { Hyperfine splitting } \\
\text { in } \mathrm{mT} \\
\pm 0.1\end{array}$ & $\begin{array}{c}\text { Peak height } \\
\text { in arbitrary unit } \\
\pm 0.01\end{array}$ \\
\hline $\begin{array}{l}\text { 4-Methylpyridine } \\
\text { in benzene }\end{array}$ & 2.115 & 5.8 & 1.0 \\
$\begin{array}{l}\text { 3-Methylpyridine } \\
\text { in benzene }\end{array}$ & 2.113 & 5.3 & 0.69 \\
$\begin{array}{l}\text { 2-Methylpyridine } \\
\text { in benzene }\end{array}$ & 2.096 & 6.4 & 0.21 \\
$\begin{array}{l}\text { Pyridine } \\
\text { in benzene }\end{array}$ & 2.115 & 5.8 & 0.66 \\
$\begin{array}{l}\text { Pyridine } \\
\text { in chloroform }\end{array}$ & 2.115 & 5.8 & 0.68 \\
\hline
\end{tabular}

Each value represents mean for six determinations. 
Table 2

Effects of $100 \mathrm{mM}$ anions on the determination of $200 \mu \mathrm{M} \mathrm{N}_{3}{ }^{-}$

\begin{tabular}{|c|c|c|c|}
\hline Group & Anions(100 mM) & Reaction with $\mathrm{Cu}^{2+}$ & $\begin{array}{l}\text { Interfering EPR } \\
\text { signals }\end{array}$ \\
\hline $\mathrm{A}$ & $\begin{array}{l}\mathrm{SO}_{4}{ }^{2-}, \mathrm{CN}^{-}, \mathrm{F}^{-}, \mathrm{HCO}_{3}{ }^{-} \\
\mathrm{HPO}_{4}{ }^{2-}, \mathrm{HSO}_{3}{ }^{-}, \mathrm{S}_{2} \mathrm{O}_{5}{ }^{2-}\end{array}$ & Weak & No \\
\hline $\mathrm{B}^{\mathrm{a}}$ & $\begin{array}{l}\text { EDTA, oxalate, citrate } \\
\text { tartrate, ascorbate, } \mathrm{S}_{2} \mathrm{O}_{3}{ }^{2-}\end{array}$ & Strong & No \\
\hline $\mathrm{C}$ & $\begin{array}{l}\mathrm{Cl}^{-}(0.09)^{\mathrm{b}}, \mathrm{Br}^{-}(0.18) \\
\mathrm{NO}_{3}^{-}(0.19) \\
\mathrm{CH}_{3} \mathrm{COO}^{-}(0.02), \mathrm{HCOO}_{4}^{-}(0.02)\end{array}$ & Weak & Small \\
\hline $\mathrm{D}$ & $\mathrm{I}^{-}, \mathrm{NO}_{2}^{-}, \mathrm{SCN}^{-}$ & Strong & Large \\
\hline
\end{tabular}

${ }^{a}$ Anions of group B gave negative errors, only when the concentrations of anions were greater than that of $\mathrm{Cu}^{2+}$.

${ }^{\mathrm{b}}$ Each value shown in parenthesis is an EPR peak height ratio of an anion at $100 \mathrm{mM}$ to $\mathrm{N}_{3}{ }^{-}$at $200 \mu \mathrm{M}$. 
Table 3

Calibration curve, quantitation range and detection limit for azide ion spiked at 5 - 2000 $\mu \mathrm{M}$ in biological fluids.

\begin{tabular}{|c|c|c|c|c|}
\hline Sample & Calibration equation & $\begin{array}{c}\text { Correlation } \\
\text { coefficient } \\
\text { (r) }\end{array}$ & $\begin{array}{l}\text { Qantitation } \\
\text { range } \\
\mu \mathrm{M}\end{array}$ & $\begin{array}{l}\text { Detection } \\
\text { limit } \\
\mu \mathrm{M}\end{array}$ \\
\hline Blood & $y=0.965 x-1.8$ & 0.998 & $15-2000$ & 15 \\
\hline Urine & $y=1.002 x+4.7$ & 0.999 & $15-2000$ & 15 \\
\hline Milk & $y=0.973 x+3.4$ & 0.998 & $50-2000$ & 15 \\
\hline Coffee & $y=0.961 x-2.2$ & 0.998 & $50-2000$ & 15 \\
\hline Green tea & $y=0.963 x+0.8$ & 0.998 & $50-2000$ & 15 \\
\hline Orange juice & $y=0.955 x-1.8$ & 0.998 & $50-2000$ & 15 \\
\hline
\end{tabular}




\section{Table 4}

Recovery and coefficient of variation of determination for azide ion spiked at 15 - 200 $\mu \mathrm{M}$ in biological fluids. Values for azide ion at 5, 500 and $2000 \mu \mathrm{M}$, see the text.

\begin{tabular}{|c|c|c|c|c|c|}
\hline \multirow[t]{2}{*}{ Sample } & \multirow{2}{*}{$\begin{array}{c}\mathrm{N}_{3}^{-} \text {added } \\
\mu \mathrm{M}\end{array}$} & \multicolumn{2}{|c|}{ Intra-day (6 times) } & \multicolumn{2}{|c|}{ Inter-day (5 days) } \\
\hline & & $\begin{array}{c}\text { Recovery } \\
\%\end{array}$ & $\begin{array}{l}\text { Coefficient of } \\
\text { variation \% }\end{array}$ & $\begin{array}{l}\text { Recovery } \\
\%\end{array}$ & $\begin{array}{l}\text { Coefficient of } \\
\text { variation \% }\end{array}$ \\
\hline \multirow[t]{3}{*}{ Blood } & 15 & 63 & 15 & 59 & 20 \\
\hline & 50 & 91 & 16 & 89 & 17 \\
\hline & 200 & 98 & 5 & 97 & 6 \\
\hline \multirow[t]{3}{*}{ Urine } & 15 & 80 & 16 & 72 & 18 \\
\hline & 50 & 100 & 10 & 96 & 12 \\
\hline & 200 & 101 & 5 & 99 & 5 \\
\hline \multirow[t]{3}{*}{ Milk } & 15 & 59 & 43 & 59 & 32 \\
\hline & 50 & 84 & 14 & 82 & 16 \\
\hline & 200 & 97 & 5 & 97 & 5 \\
\hline \multirow[t]{3}{*}{ Coffee } & 15 & 63 & 33 & 60 & 34 \\
\hline & 50 & 85 & 17 & 83 & 18 \\
\hline & 200 & 96 & 5 & 96 & 5 \\
\hline \multirow[t]{3}{*}{ Green tea } & 15 & 59 & 30 & 58 & 35 \\
\hline & 50 & 83 & 16 & 83 & 18 \\
\hline & 200 & 97 & 3 & 96 & 5 \\
\hline \multirow[t]{3}{*}{ Orange juice } & 15 & 57 & 34 & 57 & 32 \\
\hline & 50 & 82 & 15 & 80 & 16 \\
\hline & 200 & 95 & 4 & 95 & 5 \\
\hline
\end{tabular}

